\title{
Tingkat kecemasan mahasiswa Bimbingan dan Konseling dalam menyusun skripsi
}

\author{
Fauzi Marjan ${ }^{1}$, Afrizal Sano ${ }^{2}, \&$ Ifdil $^{3}$ \\ ${ }^{123}$ Universitas Negeri Padang
}

Article Info:

Accepted 12 November 2018

Published Online 22 November 2018

\begin{abstract}
Abstratc
This research is motivated by the existence of guidance and counseling students who feel anxious in preparing a essay. Anxiety is an unpleasant emotion that is characterized by worries and helplessness towards something that will happen in the future. The purpose of the reasearch was to describe the level of anxiety of guidance and counseling students in compiling the essay. Type of research is descriptive. The research subjects were 27 students. Data were analyzed by percentage techniques. The research findings reveal the level of anxiety of guidance and counseling students in compiling the essay is in the high category.
\end{abstract}

Keywords: anxiety, essay

This is an open access article distributed under the Creative Commons Attribution License, which
permits unrestricted use, distribution, and reproduction in any medium, provided the original work is
properly cited. (C) 2017 by author

\section{PENDAHULUAN}

Perguruan tinggi merupakan satuan penyelenggara pendidikan tinggi. Peserta didik perguruan tinggi disebut mahasiswa. Kuliah di perguruan tinggi menuntut mahasiswa untuk menyelesaikan tugas akhir untuk memperoleh gelar kesarjanaan bagi mahasiswa strata satu (S1), yaitu skripsi. Skripsi merupakan tantangan yang berat untuk mahasiswa tentunya bagi mahasiswa tingkat akhir yang sedang menjalaninya.

Buku Panduan Penulisan Tugas Akhir/Skripsi Universitas Negeri Padang menjelaskan skripsi sebagai laporan hasil penelitian kualitatif, kuantitatif, pengembangan, dan PTK yang ditulis mahasiswa dan dipertanggungjawabkan melalui ujian skripsi sebagai salah satu persyaratan untuk memperoleh gelar kesarjanaan (Tim Penyusun, 2017).

Proses penyusunan skripsi tidaklah mudah seperti membuat makalah-makalah pada tugas perkuliahan setiap minggunya. Penyusunan skripsi dalam Buku Panduan Penulisan Tugas Akhir/Skripsi Universitas Negeri Padang memiliki prosedur yang jelas, dimulai dari penyusunan proposal penelitian, melakukan penelitian dan penulisan skripsi, melakukan ujian skripsi hingga perbaikan dan penyerahan skripsi (Tim Penyusun, 2017).

Mahasiswa dalam menyusun skripsi menghadapi berbagai gangguan psikologis seperti stres skripsi, depresi, termasuk kecemasan. Hal ini didukung oleh hasil penelitian Linayaningsih (2007) bahwa mahasiswa dalam menyusun skripsi mengalami kecemasan berupa perasaan minder, merasa lebih bodoh, perasaan tidak mampu mengerjakan skripsi, perasaan sedih, pikiran tidak tenang, merasa tidak percaya diri, tiba-tiba merasa sakit kepala, mudah marah dan tersinggung. Juga termasuk ancaman fisik, ancaman terhadap harga diri, dan tekanan untuk melakukan sesuatu di luar kemampuan dapat menimbulkan kecemasan (Atkinson, Richard C. Atkinson, \& Hilgard, 1983). 
Keadaan khawatir terhadap sesuatu yang buruk akan terjadi dikenal dengan kecemasan (Nevid, Spencer, \& Beverly, 2005). Lebih lanjut, Nevid, dkk. (2005) menjelaskan bahwa kecemasan merupakan respons terhadap ancaman, bisa menjadi abnormal bila tingkatnya tidak sesuai dengan proporsi ancaman atau cemas tanpa sebab. Dalam redaksi lain dapat dikatakan bahwa kecemasan adalah suatu keadaan emosional yang mempunyai ciri-ciri keterangsangan fisiologis, perasaan tegang yang tidak menyenangkan, dan perasaan aprehensif terhadap sesuatu yang buruk akan terjadi (Nevid, dkk., 2005).

Stuart (2006) menyebut kecemasan sebagai kekhawatiran yang tidak menentu dan menyebar, berkaitan dengan perasaan yang tidak pasti dan tidak berdaya. Emosi yang tidak menyenangkan yang ditandai dengan gejala seperti kekhawatiran dan perasaan takut juga disebut sebagai kecemasan (Atkinson, dalam Safaria \& Nofran, 2012).

Fenomena yang peneliti temukan dari hasil wawancara dengan mahasiswa yang sedang menyusun skripsi, khususnya mahasiswa Bimbingan dan Konseling Fakultas Ilmu Pendidikan Universitas Negeri Padang angkatan 2014 sebanyak 10 orang yang terdiri dari empat orang mahasiswa laki-laki dan enam orang mahasiswa perempuan pada tanggal 12 Februari 2018 di Perpustakaan FIP UNP.

Diketahui bahwa adanya mahasiswa yang merasa takut tidak diterimanya judul proposal oleh dosen pembimbingnya. adanya mahasiswa yang mengalami ketegangan fisik dalam proses bimbingan dengan dosen pembimbing, adanya mahasiswa yang menghindari untuk berjumpa dengan dosen pembimbingnya untuk sementara waktu, adanya mahasiswa jantungnya berdebardebar dalam proses bimbingan dengan dosen pembimbingnya, adanya mahasiswa yang berkeringat dingin dalam proses bimbingan dengan dosen pembimbingnya, adanya mahasiswa yang mengaku bahwa sulit tidur di malam harinya ketika akan menjalani seminar proposal esok harinya, ada juga mahasiswa yang mengalami nafsu makan menurun. Ada juga mahasiswa yang mudah terganggu dalam menulis skripsi, tidak bisa konsentrasi dan bahkan bisa menunda-nunda menulis skrpsinya.

Selain itu, ada di antaranya mahasiswa mengalami gelisah ketika menunggu dosen penguji dalam seminar proposalnya, adanya mahasiswa yang gelisah dan mondar-mandir menunggu keputusan dosen komisi penguji, ada juga mahasiswa yang sering lupa akan barang-barangnya sehingga tertingga di tempat biasa ia duduk menunggu dosen pembimbingnya.

Adanya mahasiswa yang mengalami kebingungan tidak tahu harus melakukan apa lagi dalam melakukan perbaikan proposalnya, adanya mahasiswa yang mengaku bahwa takut akan kehilangan kendali dalam menyusun skripsinya, ada juga mahasiswa mengaku sudah kehabisan ide (hambatan berpikir) dalam menyusun instrumen penelitian. Adanya mahasiswa yang gelisah karena jadwal pelaksanaan penelitian tertunda karena harus menunggu waktu semester baru dimulai (bagi mahasiswa yang penelitiannya di sekolah).

Di samping itu, di luar wawancara yang peneliti lakukan, ada mahasiswa yang mengaku bahwa merasa deg-degan yang berlebihan dan perasaan yang tidak menentu sebelum menghadapi ujian skripsi. Adanya mahasiswa yang insomnia sebelum ujian skripsi. Juga peneliti temui, adanya mahasiswa yang khawatir akan uji keabsahan skripsinya. Berdasarkan fenomena tersebut, peneliti tertarik untuk meneliti tentang tingkat kecemasan mahasiswa bimbingan dan konseling dalam menyusun skripsi.

Penelitian ini bertujuan secara umum untuk mendeskripsikan tingkat kecemasan mahasiswa bimbingan dan konseling dalam menyusun skripsi dan secara khusus untuk mendeskripsikan tingkat kecemasan mahasiswa bimbingan dan konseling dalam menyusun skripsi ditinjau dari proses bimbingan, seminar proposal, menyusun instrumen dan pelaksanaan penelitian.

\section{METODOLOGI}

Jenis penelitian ini adalah deskriptif. Subjek dalam penelitian ini dipilih menggunakan teknik non random sampling, dengan metode purposive sampling(Sugiyono, 2010).Subjek penelitian adalah mahasiswa bimbingan dan konseling Fakultas Ilmu Pendidikan Universitas Negeri Padang sebanyak 27 orang dengan kriteria subjek penelitian adalah mahasiswa yang sudah menjalani proses bimbingan, seminar proposal, menyusun instrumen dan pelaksanaan penelitian. Data dikumpulkan dengan cara mengadministrasikan instrumen kecemasan mahasiswa dalam 
menyusun skripsi kepada responden. Data diperoleh dari mahasiswa bimbingan dan konseling Fakultas Ilmu Pendidikan Universitas Negeri Padang. Data dianalisis dengan teknik persentase.

\section{HASIL DAN PEMBAHASAN}

Hasil analsis deskriptif mengenai tingkat kecemasna mahasiswa bimbinngan dan konseling dalam menyusun skripsi dapat dilihat pada Tabel berikut ini.

Tabel 1. Deskripsi Rata-rata dan Persentase Tingkat Kecemasan Mahasiswa Bimbingan dan Konseling dalam Menyusun Skripsi

\begin{tabular}{|c|c|c|c|c|c|c|c|c|c|}
\hline \multirow{2}{*}{ No } & \multirow{2}{*}{$\begin{array}{c}\text { Kecemasan Mahasiswa } \\
\text { dalam Menyusun } \\
\text { Skripsi }\end{array}$} & \multicolumn{6}{|c|}{ Skor } & \multirow{2}{*}{$\%$} & \multirow{2}{*}{ Kat. } \\
\hline & & Ideal & Max & Min & Jumlah & Mean & SD & & \\
\hline 1 & Proses Bimbingan (8) & 40 & 38 & 15 & 690 & 25,56 & 5,19 & 63,9 & $\mathrm{~T}$ \\
\hline 2 & Seminar Proposal (13) & 65 & 59 & 29 & 1247 & 46,19 & 8,18 & 71,1 & $\mathrm{~T}$ \\
\hline 3 & $\begin{array}{l}\text { Menyusun Instrumen } \\
\text { dan Pelaksanaan } \\
\text { Penelitian (8) }\end{array}$ & 40 & 36 & 12 & 685 & 25,37 & 5,82 & 63,4 & $\mathrm{~T}$ \\
\hline & Keseluruhan & 145 & 133 & 60 & 2622 & 97,11 & 16,45 & 67 & $\mathbf{T}$ \\
\hline
\end{tabular}

Berdasarkan Tabel tersebut, dideskripsikan rata-rata tingkat kecemasan mahasiswa bimbingan dan konseling dalam menyusun skripsi dengan skor ideal 145, skor tertinggi 133 dan skor terendah 60 dengan rata-rata skor keseluruhan sebesar 97,11 dengan capaian $67 \%$ dari skor ideal yang berarti tergolong pada kategori tinggi.

Berikut ini akan dijelaskan lebih rinci tentang tingkat kecemasan mahasiswa bimbingan dan konseling dalam menyusun skripsi.

Tabel 2. Deskripsi Tingkat Kecemasan Mahasiswa

Bimbingan dan Konseling dalam Menyusun Skripsi

\begin{tabular}{cccl}
\hline Interval Skor & f & \% & \multicolumn{1}{c}{ Kategori } \\
\hline$\geq 122$ & 1 & 3,7 & Sangat Tinggi (ST) \\
\hline $99-121$ & 10 & 37 & Tinggi (T) \\
\hline $76-98$ & 15 & 55,6 & Sedang (S) \\
\hline $53-75$ & 1 & 3,7 & Rendah (R) \\
\hline$\leq 52$ & 0 & 0 & Sangat Rendah (SR) \\
\hline
\end{tabular}

Berdasarkan tabel tersebut, gambaran tingkat kecemasan mahasiswa bimbingan dan konseling dalam menyusun skripsi 3,7\% berada pada kategori sangat tinggi, $37 \%$ berada pada kategori tinggi, 55,6\% berada pada kategori sedang, 3,7\% berada pada kategori rendah, dan tidak terdapat kecemasan pada kategori sangat rendah.

Berikut ini akan dijelaskan lebih rinci tentang tingkat kecemasan mahasiswa bimbingan dan konselingdalam menyusun skripsi dilihat dari proses bimbingan, seminar proposal, menyusun instrumen dan pelaksanaan penelitian. 
Tabel 3. Deskripsi Tingkat Kecemasan Mahasiswa Bimbingan dan

Konseling dalam Menyusun Skripsi Dilihat dari Proses Bimbingan

\begin{tabular}{cccl}
\hline Interval Skor & f & \% & \multicolumn{1}{c}{ Kategori } \\
\hline$\geq 33$ & 2 & 7,4 & Sangat Tinggi (ST) \\
\hline $27-32$ & 9 & 33 & Tinggi (T) \\
\hline $21-26$ & 13 & 48,1 & Sedang (S) \\
\hline $15-20$ & 3 & 11,1 & Rendah (R) \\
\hline$\leq 14$ & 0 & 0 & Sangat Rendah (SR)
\end{tabular}

Berdasarkan tabel tersebut, gambaran tingkat kecemasan mahasiswa bimbingan dan konseling dalam menyusun skripsi dilihat dari proses bimbingan 7,4\% berada pada kategori sangat tinggi, 33\% berada pada kategori tinggi, 48,1\% berada pada kategori sedang, 11,1\% berada pada kategori rendah, dan tidak terdapat kecemasan pada kategori sangat rendah.

Tabel 4. Deskripsi Tingkat Kecemasan Mahasiswa Bimbingan dan Konseling dalam Menyusun Skripsi Dilihat dari Seminar Proposal

\begin{tabular}{cccl}
\hline Interval Skor & f & \% & \multicolumn{1}{c}{ Kategori } \\
\hline$\geq 54$ & 6 & 22,2 & Sangat Tinggi (ST) \\
\hline $44-53$ & 12 & 44 & Tinggi (T) \\
\hline $34-43$ & 8 & 29,6 & Sedang (S) \\
\hline $24-33$ & 1 & 3,7 & Rendah (R) \\
\hline$\leq 23$ & 0 & 0 & Sangat Rendah (SR)
\end{tabular}

Berdasarkan tabel tersebut, gambaran tingkat kecemasan mahasiswa bimbingan dan konseling dalam menyusun skripsi dilihat dari seminar proposal22,2\% berada pada kategori sangat tinggi, $44 \%$ berada pada kategori tinggi, 29,6\% berada pada kategori sedang, 3,7\% berada pada kategori rendah, dan tidak terdapat kecemasan pada kategori sangat rendah.

Tabel 5. Deskripsi Tingkat Kecemasan Mahasiswa Bimbingan danKonseling dalam Menyusun Skripsi Dilihat dari Menyusun Instrumen dan Pelaksanaan Penelitian

\begin{tabular}{cccl}
\hline Interval Skor & f & $\%$ & \multicolumn{1}{c}{ Kategori } \\
\hline$\geq 33$ & 2 & 7,4 & Sangat Tinggi (ST) \\
\hline $27-32$ & 12 & 44 & Tinggi (T) \\
\hline $21-26$ & 7 & 25,9 & Sedang (S) \\
\hline $15-20$ & 5 & 18,5 & Rendah (R) \\
\hline$\leq 14$ & 1 & 3,7 & Sangat Rendah (SR)
\end{tabular}

Berdasarkan tabel tersebut, gambaran tingkat kecemasan mahasiswa bimbingan dan konseling dalam menyusun skripsi dilihat dari seminar proposal7,4\% berada pada kategori sangat tinggi, $44 \%$ berada pada kategori tinggi, $25,9 \%$ berada pada kategori sedang, $18,5 \%$ berada pada kategori rendah, dan 3,7\% berada pada kategori sangat rendah.

\section{PEMBAHASAN}

Berdasarkan hasil analisis deskriptif diperoleh data rata-rata tingkat kecemasan mahasiswa bimbingan dan konseling dalam menyusun skripsi berada pada kategori tinggi. Tingkat kecemasan tinggi berarti mahasiswa bimbingan dan konseling mengalami kecemasan yang tinggi dalam menyusun skripsi. Kecemasan yang berlebihan dapat menurunkan produktivitas dan mengganggu aktivitas mahasiswa dalam menyusun skripsi. Hal ini dikuatkan oleh pendapat Nevid, dkk. (2005) bahwa kecemasan merupakan respons terhadap ancaman, bisa menjadi abnormal bila tingkatnya tidak sesuai dengan proporsi ancaman atau cemas tanpa sebab. Senada dengan itu, Stuart (2006) menjelaskan bahwa kecemasan yang tinggi sangat mengurangi lapang persepsi individu. Individu tidak dapat memikirkan hal lain, selain berfokus pada sesuatu yang rinci dan spesifik. semua perilaku ditujukan untuk mengurangi ketegangan yang dialami oleh individu. 
Tingkat kecemasan mahasiswa bimbingan dan konseling yang tinggi dalam menyusun skripsi ditandai oleh jantung berdebar kencang saat berhadapan dengan dosen pembimbing, gugup saat berhadapan dengan dosen pembimbing, dan perasaan bersalah karena tidak dapat melaksanakan bimbingan merupakan kecemasan mahasiswa bimbingan dan konseling dalam proses bimbingan.

Perasaan khawatir dosen penguji tidak dapat menghadiri seminar proposal, perasaan takut gagal saat seminar proposal, berpikir pertanyaan yang akan diajukan tim penguji sangat sulit, dan jantung berdebar kencang menunggu keputusan tim penguji saat seminar proposal merupakan kecemasan mahasiswa bimbingan dan konseling dalam seminar proposal.

Sedangkan, khawatir tidak mampu menyelesaikan masalah-masalah yang akan muncul di lapangan saat penelitian dan gelisah ketika tidak kunjung selesai merumuskan item pernyataan instrumen penelitian merupakan kecemasan mahasiswa bimbingan dan konseling dalam menyusun instrumen dan pelaksanaan penelitian.

Hasil penelitian ini juga ditemukan tingkat kecemasan mahasiswa bimbingan dan konseling pada kategori sedang. Artinya tingkat kecemasan mahasiswa bimbingan dan konseling dalam menyusun skripsi adalah sedang. Kecemasan tingkat sedang memungkinkan mahasiswa untuk fokus dalam menyusun skripsi namun tidak memperhatikan hal lainnya. Kecemasan tingkat sedang mempersempit lapang persepsi mahasiswa dalam menyusun skripsi. Stuart (2006) menganggap kecemasan sebagai sebagai kekhawatiran yang tidak menentu, perasaan yang tidak pasti dan tidak berdaya.

Tingkat kecemasan sedang yang dialami mahasiswa berupa sulit berpikir positif ketika ada permasalahan dengan dosen pembimbing dan bernapas tidak teratur ketika akan bimbingan skripsi merupakan kecemasan mahasiswa bimbingan dan konseling dalam proses bimbingan. Gugup menjelaskan materi ketika seminar proposal, tidak dapat berpikir efektif untuk menjawab pertanyaan yang diajukan tim penguji ketika seminar proposal, bernapas tidak teratur saat tim penguji memberikan pertanyaan ketika seminar proposal, takut kehilangan kendali ketika seminar proposal berlangsung, dan tangan berkeringat saat seminar proposal berlangsung merupakan kecemasan mahasiswa bimbingan dan konseling dalam seminar proposal.

Sedangkan, khawatir tidak mampu merumuskan item pernyataan dengan baik dan benar dan cenderung terfokus pada kemungkinan-kemungkinan buruk yang akan terjadi di lapangan merupakan kecemasan mahasiswa bimbingan dan konseling dalam menyusun instrumen dan pelaksanaan penelitian.

Selain itu, juga ditemukan kecemasan rendah pada mahasiswa bimbingan dan konseling dalam menyusun skripsi. Kecemasan rendah artinya tingkat kecemasan mahasiswa bimbingan dan konseling dalam menyusun skripsi adalah ringan. Menurut Stuart (2006) kecemasan ringan dapat menjadi memicu individu untuk waspada dan meningkatkan lapang persepsinya. Kecemasan ringan juga dapat menjadi motivasi bagi individu untuk belajar dan menghasilkan pertumbuhan serta meningkatkan kreativitasnya.Kecemasan rendah yang dialami oleh mahasiswa bimbingan dan konseling dalam menyusun skripsi adalah berupa memilih berdiam diri di rumah daripada bertemu dengan dosen pembimbing dan menarik diri dari lingkungan kampus ketika mengalami kesulitan dalam menyusun instrumen.

\section{KESIMPULAN}

Berdasarkan hasil penelitian yang telah dilakukan mengenai tingkat kecemasan mahasiswa bimbingan dan konseling dalam menyusun skripsi berdasarkan jenis kelamin. Rata-rata tingkat kecemasan mahasiswa bimbingan dan konseling dalam menyusun skripsi berada pada kategori tinggi. Rata-rata tingkat kecemasan ditinjau dari proses bimbingan, seminar proposal, menyusun instrumen dan pelaksanaan penelitian berada pada kategori tinggi.

\section{DAFTAR RUJUKAN}

Atkinson, Rita L., Richard C. Atkinson \& Ernest L. Hilgard. (1983). Pengantar Psikologi (Terjemahan Nurdjannah Taufiq). Jakarta: Erlangga.

Linayaningsih, Fitria. (2007). "Kecemasan pada Mahasiswa Fakultas Psikologi Universitas Katolik Soegijapranata dalam Mengerjakan Skripsi”. Laporan Penelitian. Semarang: Universitas Soegijapranata.

Nevid, Jeffrey S., Spencer A.R., \& Beverly Greene. (2005). Psikologi Abnormal. Jakarta: Erlangga. 
Safaria, Triantoro \& Nofran Eka Saputra. (2012). Manajemen Emosi. Jakarta: Bumi Aksara.

Stuart, Gail W. (2006). Buku Saku Keperawatan Jiwa (Terjemahan Ramona P. Kapoh \& Egi Komara Yudha). Jakarta: EGC.

Sugiyono. (2010). Metode Penelitian Pendidikan: Pendekatan Kuantitatif, Kualitatif, dan R\&D. Bandung: Alfabeta.

Tim Penyusun. (2017). Buku Panduan Penulisan Tugas Akhir/Skripsi Universitas Negeri Padang. Padang: UNP. 